\title{
Pengaruh Penerapan Standar Akuntansi Pemerintahan, Sistem Pengendalian Intern, Kompetensi Sumber Daya Manusia Dan Pemanfaatan Teknologi Informasi Terhadap Kualitas Laporan Keuangan Pada Pemerintah Kota Kotamobagu
}

\author{
SISKA MARINI PILANDER ${ }^{1}$, DAVID PAUL ELIA SAERANG ${ }^{2}$, HENDRIK GAMALIEL ${ }^{3}$ \\ ${ }^{1,2,3}$ Program Magister Akuntansi, Fakultas Ekonomi dan Bisnis Universitas Sam Ratulangi Manado \\ email: siskapilander@gmail.com
}

\begin{abstract}
Government financial statement is essentially a form of government accountability to the folk for the management public fund. Therefore, government shall prepare the financial statements in accordance with qualitative characteristics which are relevant, reliable, comparable, and understandable. Internal control system $\left(X_{1}\right)$, human resource competency $\left(X_{2}\right)$, and utilization of information technology $\left(X_{3}\right)$ allegedly affect the quality of financial statements. This research aims to examine the effect of implementation of the government accounting standards, internal control system, human resource competency, and utilization of information technology against the financial statements of the government of Kotamobagu city. This study used a primary type of data, and data were collected by questionnaires. There were 98 respondents from 44 SKPDs in Kotamobagu city government. Data were analysed by multiple liniar regression analysis, including validity data, test of data reliability, and classical assumption test. The data analysis was run by Statistical Product and Services Solution (SPSS) software version $22^{\text {nd }}$. As the result, it shows that the implementation of government accounting standards, internal control system, human resource competency, and utilization of information technology influence the quality of government financial statements of Kotamobagu city positively and significantly.
\end{abstract}

Keywords: Implementation of government accounting standards, internal control system, human resource competency, utilization of information technology, and financial statements quality.

Abstrak. Laporan keuangan pemerintah pada hakekatnya merupakan suatu bentuk pertanggungjawaban pemerintah kepada rakyat atas pengelolaan dana publik sehingga pemerintah wajib menyusun laporan keuangan sesuai dengan karakteristik kualitatif yakni relevan, andal, dapat dibandingkan dan dapat dipahami. Faktor-faktor yang diduga mempengaruhi kualitas laporan keuangan adalah penerapan standar akuntansi pemerintaan $\left(\mathrm{X}_{1}\right)$, sistem pengendalian intern $\left(\mathrm{X}_{2}\right)$, kompetensi sumber daya manusia $\left(\mathrm{X}_{3}\right)$, dan pemanfaatan teknologi informasi $\left(\mathrm{X}_{4}\right)$. Penelitian ini bertujuan untuk menguji pengaruh penerapan standar akuntansi pemerintahan, sistem pengendalian intern, kompetensi sumber daya manusia dan pemanfaatan teknologi informasi terhadap kualitas laporan keuangan pada pemerintah Kota Kotamobagu. Jenis data yang digunakan pada penelitian ini adalah kuantitatif dan pengumpulan data digunakan kuesioner. Dalam penelitian ini diambil sampel dari 98 responden yang terdapat pada 44 SKPD di pemerintah Kota Kotamobagu. Metode analisis data yang digunakan yaitu regresi linier berganda, dengan pengujian validitas data, uji reliabilitas data, uji asumsi klasik, dan analisis regresi berganda. Data diolah dengan menggunakan perangkat Software Statistical Product and Services Solution (SPSS) versi 22. Hasil penelitian menunjukkan bahwa penerapan standar akuntansi pemerintahan berpengaruh positif dan signifikan terhadap kualitas laporan keuangan pemerintah Kota Kotamobagu, sistem pengendalian intern berpengaruh positif dan signifikan terhadap kualitas laporan keuangan pemerintah Kota Kotamobagu, kompetensi sumber daya manusia berpengaruh positif dan signifikan terhadap kualitas laporan keuangan pemerintah Kota Kotamobagu dan pemanfaatan teknologi informasi berpengaruh positif dan signifikan terhadap kualitas laporan keuangan pemerintah Kota Kotamobagu. 
Kata Kunci: Penerapan Standar Akuntansi Pemerintahan, Sistem Pengendalian Intern, Kompetensi Sumber Daya Manusia, Pemanfaatan Teknologi Informasi Dan Kualitas Laporan Keuangan.

\section{Pendahuluan}

Salah satu bentuk pertanggungjawaban dalam penyelenggaraan pemerintah yang diatur dalam Undang-undang Nomor 17 Tahun 2003 tentang Keuangan Negara dan Undang-undang Nomor 32 Tahun 2004 tentang pemerintah daerah diharapakan dengan upaya yang konkrit untuk mampu mewujudkan transparansi dan akuntabilitas keuangan pemerintah yaitu dengan menyampaikan laporan keuangan pertanggungjawaban berupa laporan keuangan (Yosefrinaldi, 2013). Peraturan Pemerintah Nomor 71 Tahun 2010 tentang Standar Akuntansi Pemerintahan menyatakan bahwa laporan keuangan merupakan laporan yang terstruktur mengenai posisi keuangan dan transaksi-transaksi yang dilakukan oleh suatu entitas pelaporan.

Laporan keuangan yang berkualitas menunjukkan bahwa Kepala Satuan Kerja Perangkat Daerah (SKPD) bertanggung jawab sesuai dengan wewenang yang dilimpahkan kepadanya dalam pelaksanaan tanggung jawab mengelola organisasi (Azlim dkk, 2012). Bagi pemerintah daerah menjadi suatu keharusan untuk menyusun laporan keuangan yang berkualitas. Kualitas laporan keuangan pemerintah daerah mencerminkan ketertiban pengelolaan keuangan pemerintah daerah, yang mencakup tertib administrasi dan taat asas. Indikator bahwa laporan keuangan pemerintah daerah sudah berkualitas yaitu opini Wajar Tanpa Pengecualian (WTP) yang diberikan Badan Pemeriksa Keuangan (BPK) terhadap Laporan Keuangan Pemerintah Daerah (LKPD). Selain itu, proses penyusunan keuangan harus disusun sesuai dengan Peraturan Pemerintah Nomor 71 Tahun 2010 serta dilakukan secara efektif, efisien, tepat waktu dan tentunya data yang dihasilkan harus akurat dan dapat diandalkan.

Penelitian ini merupakan replikasi dari beberapa penelitian terdahulu yang dilakukan oleh Adhi dan Suhardjo (2013), Kiranayanti (2016), dan Megawati (2015). Replikasi dilakukan dengan menggabungkan empat variabel yaitu variabel penerapan standar akuntansi pemerintahan, sistem pengendalian intern, kompetensi sumber daya manusia dan pemanfaatan teknologi informasi terhadap kualitas laporan keuangan pemerintah daerah. Selain itu, penelitian ini juga mengacu pada penelitian-penelitian sebelumnya yang berkaitan dengan variabel yang digunakan dalam penelitian ini.

SAP berisikan prinsip-prinsip akuntansi pemerintahan yang diterapkan dalam menyusun dan menyajikan laporan keuangan pemerintah. SAP diterapkan di lingkup pemerintahan, baik di pemerintah pusat dan kementerian-kementeriannya maupun di pemerintah daerah (pemda) dan dinas-dinasnya. Penerapan SAP diyakini akan berdampak pada peningkatan kualitas pelaporan keuangan di pemerintah pusat dan daerah.

Sistem pengendalian intern adalah proses yang integral pada tindakan dan kegiatan yang dilakukan secara terus menerus oleh pimpinan dan seluruh pegawai untuk memberikan keyakinan memadai atas tercapainya tujuan organisasi melalui kegiatan yang efektif dan efisien. Pengendalian intern terdiri atas kebijakan dan prosedur yang digunakan dalam mencapai sasaran dan menjamin atau menyediakan informasi keuangan yang andal, serta menjamin ditaatinya hukum dan peraturan yang berlaku.

Sumber daya manusia merupakan kemampuan baik dalam tingkatan individu, organisasi atau kelembagaan, maupun sistem untuk melaksanakan fungsi-fungsi atau kewenangannya untuk mencapai tujuannya secara efektif dan efisien (GTZ dan USAID/CLEAN Urban, 2001 dalam Indriasari dkk, 2008). Hullah dkk (2012) menjelaskan bahwa sumber daya manusia adalah orang yang siap, mau dan mampu memberikan sumbangan dalam usaha pencapaian tujuan 
organisasional keandalan pelaporan keuangan, pengamanan aset negara, dan ketaatan terhadap peraturan perundang-undangan.

Teknologi informasi selain berfungsi sebagai teknologi komputer (hardware dan software) untuk pemrosesan dan penyimpanan informasi, juga memiliki fungsi sebagai teknologi komunikasi untuk penyampaian dan penyebaran informasi. Menurut Trisaputra (2013) Teknologi informasi berperan dalam menyediakan informasi yang bermanfaat bagi para pengambil keputusan di dalam organisasi termasuk dalam hal pelaporan sehingga mendukung proses pengambilan keputusan dengan lebih efektif.

Berdasarkan latar belakang dan penelitian terdahulu yang telah diuraikan sebelumnya, maka perumusan masalah dalam penelitian ini yaitu: 1) Apakah penerapan standar akuntansi pemerintahan berpengaruh terhadap kualitas laporan keuangan pemerintah Kota Kotamobagu? 2) Apakah sistem pengendalian intern berpengaruh terhadap kualitas laporan keuangan pemerintah Kota Kotamobagu? 3) Apakah kompetensi sumber daya manusia berpengaruh terhadap kualitas laporan keuangan pemerintah Kota Kotamobagu? 4) Apakah pemanfataan teknologi informasi berpengaruh terhadap kualitas laporan keuangan pemerintah Kota Kotamobagu?

Adapun tujuan dari penelitian ini adalah: 1) Untuk memperoleh bukti empiris pengaruh penerapan standar akuntansi pemerintah terhadap kualitas laporan keuangan pemerintah Kota Kotamobagu; 2) Untuk memperoleh bukti empiris sistem pengendalian intern terhadap kualitas laporan keuangan pemerintah Kota Kotamobagu; 3) Untuk memperoleh bukti empiris kompetensi sumber daya manusia terhadap kualitas laporan keuangan pemerintah Kota Kotamobagu; 4) Untuk memperoleh bukti empiris pemanfaatan teknologi informasi terhadap kualitas laporan keuangan pemerintah Kota Kotamobagu

Gambar 1

\section{Kerangka Konseptual}

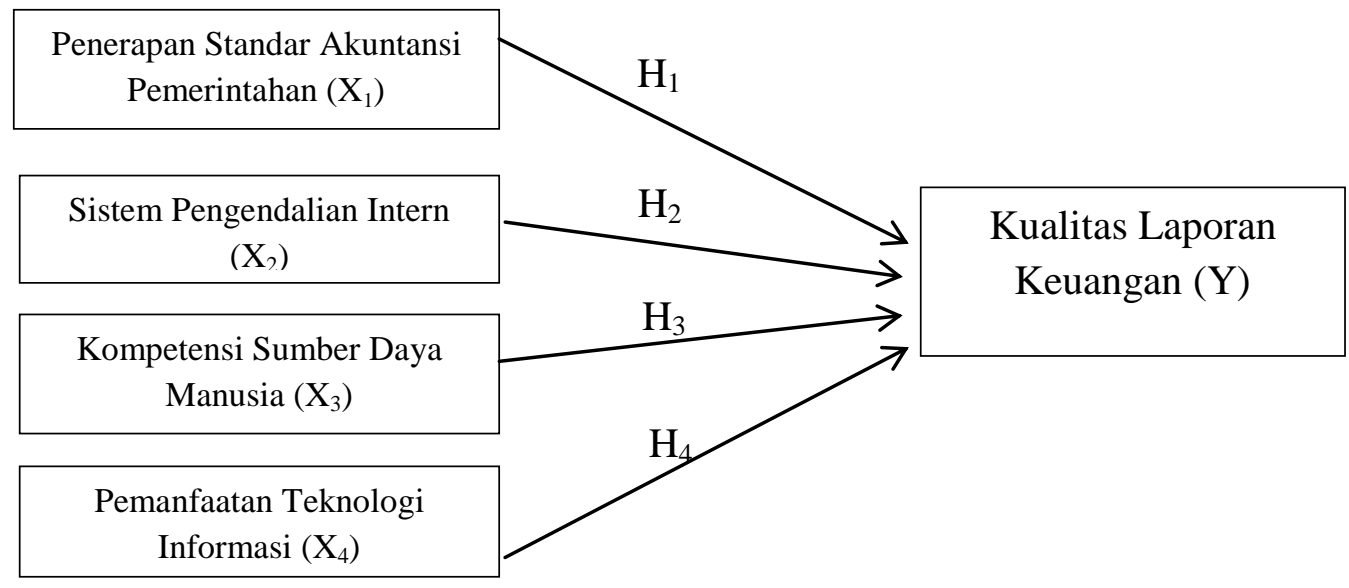

Sumber: Data olahan (2018)

Berdasarkan Gambar 1. bentuk penelitian menunjukkan suatu pengaruh antara variabel independen atau variabel bebas yaitu Kualitas Laporan Keuangan terhadap variabel dependen atau variabel terikat yaitu Standar Akuntansi Pemerintahan, Sistem Pengendalian Intern, Kompetensi Sumber Daya Manusia dan Pemanfaatan Teknologi Informasi.

Berdasarkan kajian teoritis, hasil hasil penelitian terdahulu, serta kerangka pemikiran teoritis, maka peneliti merumuskan hipotesis, sebagai berikut. 


\section{Pengaruh Penerapan Standar Akuntansi Pemerintahan terhadap Kualitas Laporan Keuangan}

Penerapan standar akuntansi pemerintahan menjamin bahwa laporan keuangan disusun sesuai dengan ketentuan yang berlaku, standar akuntansi pemerintahan merupakan standar yang menjadi acuan atau pedoman yang menjamin penyusunan laporan keuangan yang memenuhi kualifikasi informasi keuangan yang berguna untuk penggunanya dan informasi tersebut merupakan indikator bahwa laporan keuangan memenuhi kualifikasi informasi (Permadi, 2013).

Praktek pelaporan keuangan dalam organisasi sektor publik merupakan suatu konsep yang didasari oleh teori keagenan. Dalam pelaporan keuangan, pemerintah yang bertindak sebagai agen mempunyai kewajiban menyajikan informasi yang bermanfaat bagi para pengguna informasi keuangan pemerintah yang bertindak sebagai prinsipal dalam menilai akuntabilitas dan membuat keputusan baik keputusan ekonomi, sosial, maupun politik serta baik secara langsung atau tidak langsung melalui wakil-wakilnya.

Berdasarkan uraian tersebut, penelitian ini dimaksudkan untuk menguji kembali pengaruh antara penerapan standar akuntansi pemerintahan dengan kualitas laporan keuangan dengan hipotesis sebagai berikut:

$H_{1}$ : Penerapan standar akuntansi pemerintahan berpengaruh positif dan signifikan terhadap kualitas laporan keuangan

\section{Pengaruh Sistem Pengendalian Intern Terhadap Kualitas Laporan Keuangan}

Masih ditemukannya penyimpangan dan kebocoran di dalam laporan keuangan oleh BPK, menunjukkan bahwa laporan keuangan pemerintah daerah belum memenuhi karakteristik atau nilai informasi yang disyaratkan. Hasil audit BPK yang memberikan opini tidak wajar dan tidak memberikan pendapat diantaranya disebabkan oleh lemahnya sistem pengendalian intern pemerintah daerah terkait (Badan Pemeriksa Keuangan, 2016).

Implikasi teori stewardship terhadap penelitian ini, dapat menjelaskan eksistensi Pemerintah Daerah sebagai suatu lembaga yang dapat dipercaya untuk bertindak sesuai dengan kepentingan publik dengan melaksanakan tugas dan fungsinya dengan tepat, membuat pertanggungjawaban keuangan yang diamanahkan kepadanya, sehingga tujuan ekonomi, pelayanan publik maupun kesejahteraan masyarakat dapat tercapai secara maksimal.

Yosefrinaldi (2013) dalam penelitiannya memperoleh hasil bahwa sistem pengendalian intern pemerintah berpengaruh positif terhadap kualitas laporan keuangan pemerintah daerah. Kiranayanti (2016) menunjukkan bahwa sistem pengendalian intern mempunyai pengaruh positif dan signifikan terhadap kualitas laporan keuangan.

Berdasarkan uraian tersebut, penelitian ini dimaksudkan untuk menguji kembali pengaruh sistem pengendalian intern dengan kualitas laporan keuangan, dengan hipotesis sebagai berikut: $\mathrm{H}_{2}$ : Sistem pengendalian intern berpengaruh positif dan signifikan terhadap kualitas laporan keuangan.

\section{Pengaruh Kompetensi Sumber Daya Manusia Terhadap Kualitas Laporan Keuangan}

Sumber daya manuasia merupakan human capital di dalam organisasi. Human capital merupakan pengetahuan, keterampilan, dan kemampuan seseorang yang dapat digunakan untuk menghasilkan layanan profesional dan economic rent. Human capital merupakan sumber inovasi dan gagasan. Karyawan dengan human capital tinggi lebih memungkinkan untuk memberikan 
layanan yang konsisten dan berkompetensi tinggi (Sugeng dan Imam, 2000 dalam Sutaryo, 2011).

Penelitian Indriasari dan Nahartyo (2008), yang menemukan bukti empiris bahwa sumber daya manusia di sub bagian akuntansi/tata usaha keuangan yang ada di Kota Palembang dan Kabupaten Ogan Ilir diakui masih sangat kurang dari sisi jumlah maupun kualifikasinya.

Konteks penelitian ini adalah pelaporan informasi keuangan yang berkualitas,terdapat manajemen dan auditor internal yang cenderung bersikap sesuai dengan perspektif teori pengelolaan (stewardship theory). Seorang aktor yang rasional yang tidak dimotivasi oleh keinginan individualnya, tetapi lebih sebagai penerima amanah (penatalayanan) yang memiliki motif yang sejalan dengan tujuan prinsipal.

Berdasarkan uraian diatas, penelitian ini dimaksudkan untuk menguji kembali pengaruh antara kompetensi sumber daya manusia dengan kualitas laporan keuangan dengan hipotesis sebagai berikut:

$\mathrm{H}_{3}$ : Kompetensi sumber daya manusia berpengaruh positif dan signifikan terhadap kualitas laporan keuangan

\section{Pengaruh Kompetensi Pemanfaatan Teknologi Informasi Terhadap Kualitas Laporan Keuangan}

Perkembangan teknologi informasi tidak hanya dimanfaatkan pada organisasi bisnis tetapi juga pada organisasi sektor publik, termasuk pemerintahan. Dalam penjelasan Peraturan Pemerintah No. 56 Tahun 2005 tentang Sistem Informasi Keuangan Daerah disebutkan bahwa untuk menindaklanjuti terselenggaranya proses pembangunan yang sejalan dengan prinsip tata kelola pemerintahan yang baik (Good Governance), pemerintah, dan pemerintah daerah berkewajiban untuk mengembangkan dan memanfaatkan kemajuan teknologi informasi untuk meningkatkan kemampuan mengelola keuangan daerah, dan menyalurkan informasi keuangan daerah kepada pelayanan publik.

Berdasarkan uraian tersebut, penelitian ini dimaksudkan untuk menguji kembali pengaruh antara pemanfaatan teknologi informasi terhadap kualitas laporan keuangan, dengan hipotesis sebagai berikut:

$H_{4}:$ Pemanfaatan teknologi informasi berpengaruh positif dan signifikan terhadap kualitas laporan keuangan.

\section{Metode Penelitian}

Jenis data yang dianalisis dalam penelitian ini adalah data primer yang dikumpulkan melalui kuesioner dari responden dengan menggunakan SPSS versi 2.2. Isi kuesioner adalah daftar pernyataan terstruktur yang ditujukan pada responden yang dipilih secara purposive. Berdasarkan metode tersebut, maka jumlah sampel yang diambil 98 orang yang adalah Bendahara SKPD, PPK SKPD dan PNS bidang akuntansi selaku SKPD dilingkungan pemerintah Kota Kotamobagu yang memenuhi kriteria yakni pernah menyusun laporan keuangan pemerintah. Adapun metode analisis data yang digunakan dalam penelitian ini adalah analisis linear berganda. Persamaan-persamaan regresi yang digunakan dalam penelitian ini diuji dengan signifikansi 5\%, model persamaan regresi penelitian ini adalah : Model regresi berganda dalam pernyataan ini dinyatakan sebagai berikut : $\mathbf{Y}=\boldsymbol{\alpha}+\boldsymbol{\beta}_{\mathbf{1}} \mathbf{X}_{\mathbf{1}}+\boldsymbol{\beta}_{\mathbf{2}} \mathbf{X}_{\mathbf{2}}+\boldsymbol{\beta}_{\mathbf{3}} \mathbf{X}_{\mathbf{3}}+\boldsymbol{\beta}_{\mathbf{4}} \mathbf{X}_{\mathbf{4}}+\mathbf{e}$ 


$$
\text { Keterangan } \begin{aligned}
& \mathrm{Y}=\text { kualitas laporan keuangan } \\
& \alpha=\text { konstanta } \\
& \beta_{1}=\text { koefisien regresi standar akuntansi pemerintahan } \\
& \beta_{2}=\text { koefisien regresi sistem pengendalian intern } \\
& \beta_{3}=\text { koefisien regresi sumber daya manusia } \\
& \beta_{4}=\text { koefisien regresi pemanfaatan teknologi informasi } \\
& \mathrm{X}_{1}=\text { variabel Penerapan Standar Akuntansi Pemerintahan } \\
& \mathrm{X}_{2}=\text { variabel Sistem Pengendalian Intern } \\
& \mathrm{X}_{3}=\text { variabel Sumber Daya Manusia } \\
& \mathrm{X}_{4}=\text { variabel Pemanfaatan Teknologi Informasi } \\
& \text { variabel e }=\text { variabel pengganggu }
\end{aligned}
$$

\section{Hasil Penelitian dan Pembahasan}

Penelitian ini mengambil objek di Pemerintah Kota Kotamobagu. Sebanyak 100 buah kuesioner disebarkan yang adalah Bendahara SKPD, PPK SKPD dan PNS bidang akuntansi selaku SKPD dilingkungan pemerintah Kota Kotamobagu yang memenuhi kriteria yakni pernah menyusun laporan keuangan pemerintah. Dari jumlah kuesioner yang disebarkan tersebut, terdapat 98 buah kuesioner yang dikembalikan. Sehingga kuesioner yang digunakan untuk diolah adalah sebanyak 98 buah yakni dengan presentase sebesar 98,4\%. Setelah seluruh instrumen berupa kuesioner selesai ditabulasi dan diberi skor untuk setiap variabel, maka selanjutnya data tersebut diuji kualitasnya terlebih dahulu apakah reliable dan valid atau tidak. Kualitas data yang dihasilkan dari instrument yang digunakan dalam penelitian dievaluasi melalui uji validitas dan reliabilitas. Dua prosedur tersebut dilakukan untuk mengukur ketepatan dan kekonsistenan data yang dikumpulkan dari instrumen yang digunakan.

Tabel 1. Hasil Uji Reliabilitas Data Instrumen Penelitian

\section{Reliability Statistics}

\begin{tabular}{|c|c|c|}
\hline Variabel & $\begin{array}{c}\text { Cronbach's } \\
\text { Alpha }\end{array}$ & Keterangan \\
\hline Penerapan SAP & .759 & Reliabel \\
\hline $\begin{array}{c}\text { Sistem Pengendalian } \\
\text { Intern }\end{array}$ & .780 & Reliabel \\
\hline Kompetensi SDM & .768 & Reliabel \\
\hline Pemanfaatan TI & .782 & Reliabel \\
\hline $\begin{array}{c}\text { Kualitas Laporan } \\
\text { Keuangan }\end{array}$ & .763 & Reliabel \\
\hline
\end{tabular}

Sumber: Data hasil olahan SPSS 22 (2018)

Berdasarkan tabel 1 tersebut dapat dilihat bahwa seluruh item instrumen variabel penerapan standar akuntansi pemerintahan (X1), sistem pengendalian intern $\left(\mathrm{X}_{2}\right)$, kompetensi sumber daya manusia $\left(\mathrm{X}_{3}\right)$, pemanfaatan teknologi Informasi $\left(\mathrm{X}_{4}\right)$ dan kualitas laporan keuangan (Y) dikatakan reliabel karena memiliki nilai Cronbach's Alpha > 0,60 sehingga layak digunakan untuk diujikan ke pengujian selanjutnya. 


\section{Hasil Uji Asumsi Klasik Uji Normalitas}

Uji normalitas dengan metode Kolmogorov-Smirno dapat dideteksi dengan melihat nilai signifikansi residual. Jika signifikansi lebih dari 0,05 maka hal tersebut menunjukkan bahwa residual terdistribusi secara normal, dengan demikian memenuhi asumsi normalitas. Hasil uji Kolmogorov-Smirnov menyatakan bahwa nilai signifikansi Kolmogorov-Smirnov dari unstandarized residual adalah sebesar 0,170 yang berarti nilai ini lebih besar dari 0,05. Dengan demikian melalui uji Kolmogorov-Smirnov dapat disimpulkan bahwa residual terdistribusi secara normal dan memenuhi asumsi normalitas.

\section{Uji Multikolinearitas}

Hasil nilai tolerance dari masing-masing variabel independen lebih dari 0,1 dan nilai VIF dari masing-masing variabel independen kurang dari 10, yaitu nilai tolerance untuk variabel penerapan standar akuntansi pemerintahan $\left(\mathrm{X}_{1}\right)$ adalah sebesar $0,245>0,1$ dan nilai VIF 4,081 < 10 ; nilai tolerance untuk variabel sistem pengendalian intern $\left(X_{2}\right)$ adalah sebesar $0,398>0,1$ dan nilai VIF 2,513 < 10; nilai tolerance untuk variabel kompetensi sumber daya manusia $\left(\mathrm{X}_{3}\right)$ adalah sebesar 0,282 >0,1 dan nilai VIF 3,547 < 10; pemanfaatan teknologi Informasi $\left(\mathrm{X}_{4}\right)$ adalah sebesar $0,303>0,1$ dan nilai VIF $3,298<10$; dan dengan demikian dapat disimpulkan bahwa tidak terjadi gejala multikolinearitas antara variabel penerapan standar pemerintah, sistem pengendalian intern, kompetensi sumber daya manusia dan pemanfaatan teknologi informasi.

\section{Uji Heteroskedastisitas}

Berdasarkan hasil uji tersebut dapat diketahui bahwa nilai signifikansi uji t keempat variabel independen dengan absolute residual adalah lebih dari $0,05(0,192 ; 0,172 ; 0,906 ; 0,136)$ Sehingga melalui uji Grejser dapat disimpulkan bahwa tidak ada masalah heteroskedastisitas pada model regresi ini.

\section{Analisis Koefisien Determinasi $\left(\mathbf{R}^{\mathbf{2}}\right)$}

Berdasarkan output model summary, besarnya adjusted $\mathrm{R}$ square (koefisien determinasi yang telah disesuaikan) adalah 0,904. Nilai ini menunjukkan bahwa 90,4\% variasi kualitas laporan keuangan dapat dijelaskan dari keempat variabel independen yaitu penerapan standar akuntansi pemerintahan, sistem pengendalian intern, kompetensi sumber daya manusia dan pemanfaatan teknologi informasi, sedangkan sisanya 9,6\% dijelaskan oleh sebab lain diluar model.

\section{Uji Signifikansi}

\section{Pengujian Hipotesis 1}

Hasil pengujian hipotesis pada penelitian ini menjawab bahwa standar akuntansi pemerintahan berpengaruh terhadap kualitas laporan keuangan. Hasil pengujian statistik menunjukkan bahwa nilai koefisien regresi variabel standar akuntansi pemerintahan adalah 0,198, artinya standar akuntansi pemerintahan memberikan kontribusi sebesar 19,8\% terhadap kualitas laporan keuangan pemerintah Kota Kotamobagu. Nilai ini signifikan pada tingkat signifikansi 0,05 dengan $p$ value 0,003 . Hal ini didukung dengan dengan hasil perhitungan nilai

$\mathrm{t}_{\text {hitung }} 6,926>\mathrm{t}_{\text {tabel }} 1,985$. Hal ini menunjukkan variabel penerapan standar akuntansi pemerintahan berpengaruh positif dan signifikan terhadap kualitas laporan keuangan. 


\section{Pengujian Hipotesis 2}

Hasil pengujian hipotesis pada penelitian ini menjawab bahwa sistem pengendalian intern berpengaruh terhadap kualitas laporan keuangan. Hasil pengujian statistik menunjukkan bahwa nilai koefisien regresi variabel penerapan sistem pengendalian intern adalah 0,288 , artinya dengan adanya sistem pengendalian intern laporan keuangan pemerintah Kota Kotamobagu meningkat $28,8 \%$. Nilai ini signifikan pada tingkat signifikansi 0,05 dengan $p$ value 0,000 . Hal ini didukung dengan dengan hasil perhitungan nilai $t_{\text {hitung }} 6,592>t_{\text {tabel }} 1,985$. Hal ini menunjukkan bahwa sistem pengendalian intern berpengaruh positif dan signifikan terhadap kualitas laporan keuangan.

\section{Pengujian Hipotesis 3}

Hasil pengujian hipotesis pada penelitian ini menjawab bahwa kompetensi sumber daya manusia berpengaruh terhadap kualitas laporan keuangan. Hasil pengujian statistik menunjukkan bahwa nilai koefisien regresi variabel kompetensi sumber daya manusia adalah 0,512 , artinya kompetensi sumber daya manusia memberi kontribusi sebesar $51,2 \%$ atas kualitas laporan keuangan pemerintah Kota Kotamobagu. Nilai ini signifikan pada tingkat signifikansi 0,00 dengan $p$ value 0,005 . Hal ini didukung dengan hasil perhitungan nilai $\mathrm{t}_{\text {hitung }} 2,840>\mathrm{t}_{\text {tabel }} 1,985$. Hasil ini menunjukkan bahwa kompetensi SDM berpengaruh positif dan signifikan terhadap kualitas laporan keuangan.

\section{Pengujian Hipotesis 4}

Hasil pengujian hipotesis pada penelitian ini menjawab bahwa pemanfaatan teknologi informasi berpengaruh terhadap kualitas laporan keuangan. Hasil pengujian statistik menunjukkan bahwa nilai koefisien regresi variabel pemanfaatan teknologi informasi adalah 0,219, artinya pemanfaatan teknologi informasi memberi kontribusi sebesar 21,9\% atas kualitas laporan keuangan pemerintah Kota Kotamobagu. Nilai ini signifikan pada tingkat signifikansi 0,007 dengan $p$ value 0,005 . Hal ini didukung dengan hasil perhitungan nilai $t_{\text {hitung }} 2,840>t_{\text {tabel }}$ 1,985. Hasil ini menunjukkan bahwa pemanfaatn teknologi berpengaruh positif dan signifikan terhadap kualitas laporan keuangan.

\section{Pengaruh Penerapan Standar Akuntansi Pemerintahan Terhadap Kualitas Laporan Keuangan}

Penerapan standar akuntansi pemerintahan di Kota Kotamobagu telah cukup baik, namun belum maksimal, karena hanya 19,8\% kontribusi standar akuntansi pemerintahan terhadap kualitas laporan keuangan. Hal tersebut dipengaruhi karena pengelola keuangan di tingkat SKPD yang ada di Kota Kotamobagu sebagian besar tidak memiliki latar belakang pendidikan akuntansi, sehingga pemahaman dan penerapan standar akuntansi pemerintahan berbasis akrual di tingkat SKPD belum maksimal.

Dalam pengujian ini, teori keagenan digambarkan lewat kewajiban pemerintah dalam menyusun laporan keuangan sebagai bentuk pertanggungjawaban atas pengelolaan keuangan dan kekayaan daerah yang telah diamanahkan oleh publik. Laporan keuangan harus disusun sesuai dengan standar akuntansi pemerintah dengan memuat informasi mengenai posisi keuangan dan seluruh transaksi yang dilakukan selama satu periode pelaporan.

Hasil penelitian ini mendukung hasil penelitian Juwita (2013) dan Sudiarianti (2014) yang menunjukkan bahwa terdapat pengaruh positif dan signifikan dari SAP terhadap kualitas 
laporan keuangan pemerintah daerah. Hal senada juga disampaikan dalam penelitian Tarigan (2013) yang menyatakan bahwa penerapan standar akuntansi pemerintah berbasis akrual, dapat mewujudkan akuntabilitas dan transparansi pengelolaan keuangan terutama dalam hal informasi aset pemerintah. Sehingga dapat disimpulkan penerapan standar akuntansi yang baik oleh instansi pemerintah akan menghasilkan laporan keuangan instansi pemerintah yang baik.

\section{Pengaruh Sistem Pengendalian Intern terhadap Kualitas Laporan Keuangan}

Berdasarkan hasil penelitian ini dapat disimpulkan adanya hubungan antara sistem pengendalian intern dengan kualitas laporan keuangan. Hasil penelitian ini juga mendukung hasil penelitian Kiranayanti (2016) menunjukkan bahwa sistem pengendalian intern mempunyai pengaruh positif dan signifikan terhadap kualitas laporan keuangan dan penelitian ini juga sejalan dengan penelitian Indriasari (2008), menyatakan bahwa sistem pengendalian intern berpengaruh signifikan positif terhadap kualitas laporan keuangan pemerintah daerah. Informasi akuntansi yang menunjang kelancaran kerja sistem informasi akuntansi adalah pengendalian internal.

Teori stewardship terhadap penelitian ini digambarkan lewat eksistensi Pemerintah Daerah sebagai suatu lembaga yang dapat dipercaya untuk bertindak sesuai dengan kepentingan publik dengan melaksanakan tugas dan fungsinya dengan tepat, membuat pertanggungjawaban keuangan yang diamanahkan kepadanya, sehingga tujuan ekonomi, pelayanan publik maupun kesejahteraan masyarakat dapat tercapai secara maksimal.

\section{Pengaruh Kompetensi Sumber Daya Manusia Terhadap Kualitas Laporan Keuangan}

Sikap kerja dapat menjadi kompetensi terkuat dalam meningkatkan kinerja. Seseorang dengan sikap kerja yang tinggi, walaupun ditugaskan dengan pekerjaan yang tidak sesuai dengan bidangnya, mampu beradaptasi dan memberi output yang memuaskan.

Penempatan pengelola keuangan pada pemerintah Kota Kotamobagu cenderung tidak memperhatikan latar belakang akademis menuntut adanya adaptasi dengan kondisi tersebut. Para pengelola keuangan tersebut harus mampu mengembangkan pengetahuannya lewat sosialisasi dan bimbingan teknis terkait pengelolaan keuangan khususnya SAP berbasis akrual yang diselenggarakan pemerintah kota Kotamobagu setiap tahunnya. Disamping itu pengelola keuangan harus mampu mengembangkan keterampilannya dalam menyusun laporan keuangan baik LRA, LO, LPE, neraca, dan CaLK di tingkat SKPD sehingga mampu menyusun dan menyajikan laporan keuangan yang berkualitas.

Seseorang yang ditempatkan sesuai dengan kompetensinya tentunya akan lebih mampu mengambil keputusan dan memecahkan masalah yang berkaitan dengan pekerjaannya. Hal tersebut juga dapat membentuk pribadi yang lebih percaya diri dalam melakukan pekerjaannya sehingga dapat meningkatkan prestasi dalam pekerjaannya.

Teori kegunaan keputusan dalam pengujian ini digambarkan lewat dampak penempatan SDM yang sesuai dengan kompetensinya. Penempatan pegawai pengelola keuangan yang sesuai dengan bidangnya tentunya dapat mempermudah koordinasi antara SKPD dan SKPKD dalam pengelolaan keuangan daerah.

Berdasarkan hasil penelitian ini dapat disimpulkan adanya hubungan antara kompetensi sumber daya manusia dengan kualitas laporan keuangan. Hasil penelitian ini juga mendukung hasil penelitian Sudiarianti (2014) dan Andini (2015) dan yang menunjukkan bahwa terdapat pengaruh positif dan signifikan dari kompetensi sumber daya manusia terhadap kualitas laporan 
keuangan pemerintah daerah. Hasil tersebut dapat dipahami bahwa untuk meningkatkan kualitas laporan keuangan, seorang pengelola keuangan harus memiliki kompetensi SDM seperti pengetahuan, keterampilan dan sikap yang mau terus belajar.

\section{Pengaruh Pemanfaatan Teknologi Informasi Terhadap Kualitas Laporan Keuangan}

Hasil penelitian ini menunjukkan bahwa kompetensi SDM berpengaruh positif dan signifikan terhadap kualitas laporan keuangan. Hal ini menunjukkan bahwa pemanfaatan teknologi informasi berpengaruh signifikan terhadap kualitas laporan keuangan. Dengan demikian para pengelola keuangan di tingkat SKPD dan SKPKD pada pemerintah Kota Kotamobagu semakin terbantu dalam melaksanakan tugasnya karena dengan adanya software yang sesuai dengan peraturan pemerintah yang berlaku dan mempermudah dalam menghasilkan laporan keuangan yang mampu memenuhi karakteristik kualitiatif yakni relevan, andal, dapat dibandingkan dan dapat dipahami.

Dalam pengujian ini, teori keagenan digambarkan lewat peran pemerintah terhadap publik dalam memberikan informasi yang dibutuhkan terkait pengelolaan keuangan daerah yang telah diamanahkan. Pemerintah selaku agents harus mampu memberikan informasi pengelolaan keuangan daerah sebagai pertanggungjawaban atas pelimpahan kekuasaan pengelolaan keuangan daerah oleh publik. .

Hasil penelitian ini sejalan dengan penelitian Indriasari (2008), menyatakan bahwa pemanfaatan teknologi informasi berpengaruh signifikan positif terhadap kualitas laporan keuangan pemerintah daerah. Teknologi informasi dapat dimanfaatkan jika jumlah kuantitas dan kualitasnya baik, serta tersedianya sarana penunjang yang dibutuhkan seperti jaringan dan software.

Implikasi teori stewardship terhadap penelitian ini, dapat menjelaskan eksistensi Pemerintah Daerah sebagai suatu lembaga yang dapat dipercaya untuk bertindak sesuai dengan kepentingan publik dengan melaksanakan tugas dan fungsinya dengan tepat, membuat pertanggungjawaban keuangan yang diamanahkan kepadanya, sehingga tujuan ekonomi, pelayanan publik maupun kesejahteraan masyarakat dapat tercapai secara maksimal.

Good corporate governance proses pengambilan keputusan akan berlangsung secara lebih baik sehingga akan menghasilka keputusan yang optimal, dapat meningkatkan efisiensi serta terciptanya budaya kerja yang lebih sehat. Ketiga hal ini jelas akan sangat berpengaruh positif terhadap kinerja perusahaan, sehingga kinerja perusahaan atau organisasi akan mengalami peningkatan.

\section{Penutup}

Berdasarkan hasil penelitian dan pembahasan tentang Pengaruh Penerapan Standar Akuntansi Pemerintahan, Sistem Pengendalian Intern, Kompetensi Sumber Daya Manusia dan Pemanfaatan Teknologi Informasi terhadap Kualitas Laporan Keuangan pada Pemerintah Kota Kotamobagu dapat diambil kesimpulan sebagai berikut.

1. Hasil pengujian variabel penerapan standar akuntansi pemerintahan terhadap kualitas laporan keuangan diperoleh nilai $p$ value sebesar 0,003 lebih kecil dari 0,05 maka dapat disimpulkan bahwa penerapan standar akuntansi pemerintahan berpengaruh secara positif dan signifikan terhadap kualitas laporan keuangan Kota Kotamobagu.

2. Hasil pengujian variabel sistem pengendalian intern terhadap kualitas laporan keuangan diperoleh nilai $p$ value sebesar 0,000 lebih kecil dari 0,05 maka dapat disimpulkan bahwa 
sistem penendalian intern berpengaruh positif dan signifikan terhadap kualitas laporan keuangan Kota Kotamobagu.

3. Hasil pengujian variabel kompetensi sumber daya manusia terhadap kualitas laporan keuangan diperoleh nilai $p$ value sebesar 0,000 lebih kecil dari 0,05 maka dapat disimpulkan bahwa kompetensi sumber daya manusia berpengaruh positif dan signifikan terhadap kualitas laporan keuangan Kota Kotamobagu.

4. Hasil pengujian variabel pemanfaatan teknologi informasi terhadap kualitas laporan keuangan diperoleh nilai $p$ value sebesar 0,007 lebih kecil dari 0,05 maka dapat disimpulkan bahwa pemanfaatan teknologi informasi berpengaruh positif dan signifikan terhadap kualitas laporan keuangan Kota Kotamobagu.

Saran yang dapat diberikan adalah sebaiknya semakin ditingkatkannya intensitas pelatihan pada para pengelola keuangan berupa sosialisasi dan bimbingan teknis yang berkaitan dengan implementasi standar akuntansi pemerintahan, sehingga pelatihan yang dilaksanakan dapat semakin meningkatkan pemahaman dan penerapan standar akuntansi pemerintahan, Pemerintah Kota Kotamobagu diharapkan dapat memperbaiki sistem pengendalian internal pemerintah agar berjalan seefektif mungkin, salah satunya dengan meningkatkan pemantauan dan melakukan evaluasi terus-menerus agar seluruh kegiatan operasionalnya dapat terpantau dengan baik, Pemerintah Kota Kotamobagu sebaiknya dalam menempatkan sumber daya manusia pengelola keuangan di tingkat SKPD disesuaikan dengan kompetensi sumber daya manusia tersebut. Pengelola keuangan haruslah memiliki pengetahuan dan keterampilan di bidang akuntansi sehingga semakin meningkatkan pengelolaan keuangan dan penyusunan laporan keuangan pemerintah Kota Kotamobagu, Pemerintah Kota Kotambagu kiranya dalam pemanfaatan teknologi informasi akan selalu menfasilitasi pengelola keuangan agar supaya membantu mempercepat proses pengolahan data transaksi dan penyajian laporan keuangan pemerintah sehingga laporan keuangan tersebut tidak kehilangan nilai informasinya yaitu ketepatwaktuan.

\section{Daftar Pustaka}

Adhi, Daniel Kartika dan Suhardjo, Yohanes. 2013. Pengaruh Penerapan Standar Akuntansi Pemerintahan dan Kualitas Aparatur Pemerintah Daerah Terhadap Kualitas Laporan Keuangan (Studi Kasus Pada Pemerintah Kota Tual. Jurnal Ilmiah. STIE Semarang. Semarang.

Andini, Dewi. 2015. Pengaruh Kompetensi SDM dan Penerapan Sistem Akuntansi Keuangan Daerah terhadap Kualitas Laporan Keuangan Daerah pada Satuan Kerja Perangkat Daerah (SKPD) Kabupaten Emapt Lawang Sumatera Selatan. Jurnal Ilmiah. Universitas Islam. Riau

Azlim, Darwanis, dan Bakar, Usman Abu. 2012. Pengaruh Penerapan Good Government Governance dan Standar Akuntansi Pemerintahan Terhadap Kualitas Informasi Keuangan. Jurnal Ilmiah. Universitas Syiah Kuala Banda Aceh. Banda Aceh.

Badan Kepegawaian Pendidikan dan Pelatihan (BKPP) Kota Kotamobagu 2018. Data PNS Kota Kotamobagu

Badan Pemeriksa Keuangan Republik Indonesia. 2016. Ikhtisar Hasil Pemeriksaaan Semester. www.bpk.go.id.

Hullah, Abdurahman Rigel, Pangemanan, Sifrid, Tangkuman, Steven dan Budiarso, Novi. 2012. Pengaruh Sumber Daya Manusia dan Pemanfaatan Teknologi Informasi terhadap 
Keterandalan Pelaporan Keuangan Pada Pemerintahan Sulawesi Utara. Jurnal Riset Akuntansi. Universitas Sam Ratulangi. Manado.

Indriasari, Desi dan Nahartyo, Ertambang. 2008. Pengaruh Kapasitas Sumber Daya Manusia, Pemanfaatan Teknologi Informasi dan Pengendalian Intern Akuntansi Terhadap Nilai Informasi Pelaporan Keuangan Pemerintah Daerah (Studi pada Pemerintah Kota Palembang dan Kabupaten Ogan Illir). Jurnal Ilmiah. Kumpulan Makalah Simposium Nasional Akuntansi XI. 23-24 Juli. Pontianak.

Juwita, Rukmi. 2013. Pengaruh Implementasi Standar Akuntansi Pemerintahan dan Sistem Informasi Akuntansi Terhadap Kualitas Laporan Keuangan. Jurnal Ilmiah. Politeknik Pos Indonesia. Bandung.

Kota Kotamobagu. 2018.Tentang Kota Kotamobagu.http://kotamobagukota.go.id

Kiranayanti, Ida Ayu Enny. 2016. Pengaruh Sumber Daya Manusia, Sistem Pengendalian Intern, Pemahaman Basis Akrual Terhadap Kualitas Laporan Keuangan Daerah. Jurnal Ilmiah. Universitas Udayana. Bali.

Megawati, Luh Kadek. 2015. Pengaruh Penerapan Sistem Akuntansi Keuangan Pemerintah Daerah, Kompetensi Sumber Daya Manusia dan Pengelolaan Keuangan Daerah Terhadap Kualitas Laporan Keuangan Pemerintah Daerah (Studi Empiris Pada Tiga Dinas Kabupaten Buleleng). Jurnal Ilmiah. Universitas Pendidikan Ganesha Singaraja. Bali.

Permadi, Angga Dwi. 2013. Pengaruh Penerapan Sistem Akuntansi Keuangan Pemerintah Daerah terhadap Kualitas Laporan Keuangan Pemerintah Daerah (studi kasus pada Dinas Bina Marga Provinsi Jawa Barat). Jurnal Ilmiah. Universitas Widyatama. Bandung

Sudiarianti, Ni. Made. 2014. Pengaruh Kompetensi Sumber Daya Manusia pada Penerapan Sistem Pengendalian Internal Pemerintah dan Standar Akuntansi Pemerintah dan Implikasinya Terhadap Kualitas Laporan Keuangan Pemerintah Daerah. Thesis. Bali: Universitas Udayana.

Sutaryo. 2011. Nilai Laporan Keuangan Pemerintah Dengan E-Government System. Jurnal Ilmiah. Universitas Negeri Semarang. Semarang.

Tarigan, Erwinton Putra Antonius. 2013. Standar Akuntansi Pemerintahan Dalam Mewujudkan Akuntabilitas dan Transparansi Pengelolaan Keuangan Daerah pada Dinas Pajak Daerah dan Pengelolaan Keuangan Kota Yogyakarta. Jurnal Kebijakan dan Administrasi Publik, Vol. 18, No. 1, Mei 2013, hal: 29-45. ISSN 0852-9213. Yogyakarta: Magister Administrasi Publik Universitas Gadjah Mada

Trisaputra, A. 2013. Pengaruh Pemanfaatan Teknologi Informasi dan Pengawasan Ketepatwaktuan Pelaporan Keuangan Pemerintah Daerah (Studi Empiris pada SKPD Pemerintah Provinsi Sumatera Barat). Jurnal Ilmiah. Universitas Negeri Padang. Padang.

Yosefrinaldi. 2013. Pengaruh Kapasitas Sumber Daya Manusia dan Pemanfaatan Teknologi Informasi Terhadap Kualitas Laporan Keuangan Pemerintah Daerah Dengan Variable Intervening Pengendalian Intern Pemerintah (Studi Empiris pada Dinas Pengelolaan Keuangan dan Aset Daerah Se-Sumatera Barat). Jurnal Ilmiah. Universitas Negeri Padang. Padang. 